\title{
PENERAPAN METODE CROSSDOCKING UNTUK MEMINIMUMKAN BIAYA DISTRIBUSI DAN PERSEDIAAN PADA PT. XYZ
}

\author{
St Nova Meirizha, Ari Andriyas Puji, Ardi Adrian \\ Program Studi Teknik Industri, Fakultas Teknik, Universitas Muhammadiyah Riau \\ Jalan Tuanku Tambusai Ujung, Kecamatan Tampan, Kelurahan Delima, Kota Pekanbaru, Riau 28291
}

Email: novameirizha@umri.ac.id

\begin{abstract}
Rapid technological development changes the form of competition between profit-oriented companies. The presence of new methods of company management is getting more intense due to the demands of a competitive advantage with other companies. One of the areas that can create competitive advantage is the operational sector. Furthermore, Supply Chain Management has become one of the main components as a competitive strategy to develop the productivity and profitability capabilities of a company. Meanwhile, crossdocking systems have been found for a long time, but the application is often not too significant for companies and there is still room for optimization. Therefore, the researcher was interested in carrying out research related to crossdocking. In this study, the target company is PT. XYZ as a distribution center company that has problems in managing distribution costs and supplies to its partners. By implementing crossdocking, it can help companies in minimizing distribution and inventory costs. The steps in this study are determining vehicle distribution routes, calculating the number of distribution fleets, scheduling distribution fleets, calculating the total safety stock and calculating the ratio of the total cost of supplies in the current condition to the proposed conditions. The research results obtained 2 optimal distribution routes with a total distribution fleet of 2 units, divided into fleet 1 with a capacity of 800 units and fleet 2 with a capacity of 767 units. As for the scheduling results, the makespan value of each fleet is obtained, namely 240 minutes for fleet 1 and 248 minutes for fleet 2 . The amount of safety stock for each type of cellphone is Y19 with 27 units of safety stock, Y12 with 102 units of safety stock, Y30 with safety stock 75 units and V19 with safety stock 54 units. The total cost of supplies is 2,989,055 rupiah in one order process.
\end{abstract}

Keywords: crossdocking, distribution center, retail industry, safety stock, inventory.

\begin{abstract}
Abstrak
Teknologi yang berkembang dengan cepat mengubah bentuk persaingan antar perusahaan-perusahaan yang berorientasi pada profit. Kehadiran metode-metode baru dalam pengelolaan perusahaan semakin gencar dikarenakan tuntutan suatu keunggulan bersaing dengan perusahaan lainnya. Salah satu ruang lingkup yang mampu menciptakan keunggulan bersaing adalah bidang operasional. Supply Chain Management telah menjadi salah satu komponen utama sebagai suatu strategi kompetitiff untuk mengembangkan kemampuan produktifitas dan profitabilitas suatu perusahaan. Sistem crossdocking telah lama ditemukan, hanya saja penerapannya yang kerap belum terlalu signifikan terhadap perusahaanperusahaan dan masih terdapat ruang untuk melakukan optimalisasi menjadikan peneliti tertarik untuk melakukukan penelitian terkait dengan crossdocking. Pada penelitian ini perusahaan yang dituju adalah PT.XYZ sebagai perusahaan distribution center yang memiliki permasalahan dalam mengelola biaya ditribusi dan persediaan terhadap mitra-mitranya. Dengan penerapan crossdocking dapat membantu perusahaan dalam meminimalkan biaya distribusi dan persediaan. Langkah dalam penelitian ini adalah penentuan rute distribusi kendaraan, menghitung jumlah armada distribusi, penjadwalan armada distribusi, menghitung jumlah safety stock dan menghitung perbandingan total biaya persedian kondisi saat ini dengan kondisi usulan. Hasil penelitian didapat 2 rute distribusi optimal dengan jumlah armada distribusi 2 unit yang terbagi atas armada 1 dengan kapasitas 800 unit dan armada 2 dengan kapasitas 767 unit. Sedangkan untuk hasil penjadwalan didapat nilai makespan dari masing-masing armada yaitu 240
\end{abstract}


menit untuk armada 1 dan 248 menit untuk armada 2. Jumlah safety stock untuk masing-masing tipe Handphone yaitu Y19 dengan safety stock 27 unit, Y12 dengan safety stock 102 unit, Y30 dengan safety stock 75 unit dan V19 dengan safety stock 54 unit. Untuk total biaya persedian didapat 2.989.055 rupiah dalam sekali pemesanan

Kata kunci: crossdocking, distribution center, industri retail, safety stock, persediaan

\section{Pendahuluan}

PT. XYZ sebagai perusahaan distributor Handphone yang sedang berkembang saat ini yaitu brand VIVO. Perusahaan tersebut berdiri pada tahun 2015 yang beralamat di jalan suka terus. Seiring perkembangan teknologi dan semakin dikenalnya Handphone dengan brand VIVO maka perusahaan membutuhkan perkantoran yang lebih besar untuk memenuhi permintaan dari mitra-mitranya, sehingga pindah alamat ke jalan Teuku Umar no. 21 dan 24.

PT. XYZ memiliki 156 mitra yang terdiri dari 68 mitra besar yang tersebar di wilayah RIAU daratan dengan permintaan rata-rata 230 unit/bulan. Permintaan tersebut di distribusikan secara acak sesuai dengan keinginan pengemudi, dikarenakan belum memiliki rute tetap. Padahal mitra-mitra tersebut sudah pasti akan melakukan permintaan Handphone, sehingga terjadi peningkatan biaya distribusi setiap tahunnya. Biaya Distribusi

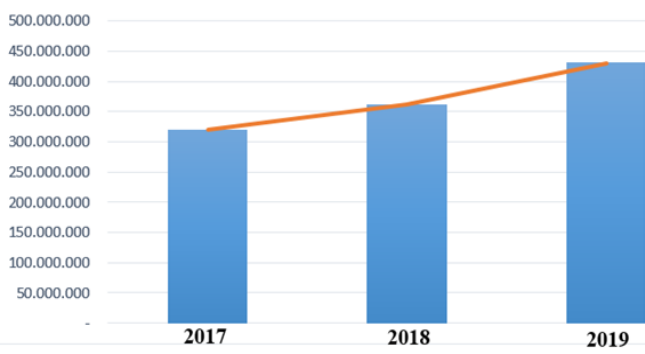

Gambar 1.1. Grafik Biaya Distribusi PT. XYZ

Dalam meningkat pelayanan terhadap pelanggan perusahaan harus mengeluarkan biaya yang besar untuk persediaan. Seperti terlihat pada tabel berikut.

Tabel 1.1. Rekapitulasi Biaya Persediaan

\begin{tabular}{|c|c|c|c|}
\hline No & Bulan & \multicolumn{2}{|c|}{$\begin{array}{c}\text { Biaya Persediaan } \\
\text { Handphone }\end{array}$} \\
\hline 1 & Apr-19 & $\mathrm{Rp}$ & 964.909 .000 \\
\hline 2 & Mei-19 & $\mathrm{Rp}$ & 2.185 .700 .000 \\
\hline 3 & Jun-19 & $\mathrm{Rp}$ & 3.221 .097 .000 \\
\hline 4 & Jul-19 & $\mathrm{Rp}$ & 922.179 .500 \\
\hline 5 & Agut 19 & $\mathrm{Rp}$ & 1.086 .195 .000 \\
\hline 6 & Sep-19 & $\mathrm{Rp}$ & 968.603 .900 \\
\hline 7 & Okt- 19 & $\mathrm{Rp}$ & 977.189 .400 \\
\hline 8 & Nov-19 & $\mathrm{Rp}$ & 2.855 .237 .000 \\
\hline 9 & Des- 19 & $\mathrm{Rp}$ & 5.057 .800 .000 \\
\hline 10 & Jan-20 & $\mathrm{Rp}$ & 2.593 .800 .000 \\
\hline 11 & Feb-20 & $\mathrm{Rp}$ & 997.266 .600 \\
\hline 12 & Mar-20 & $\mathrm{Rp}$ & 989.990 .100 \\
\hline \multicolumn{2}{|c|}{ Total } & $\mathbf{R p}$ & 22.819.967.500 \\
\hline \multicolumn{2}{|c|}{ Rata-rata } & $\mathbf{R p}$ & 1.901.663.958 \\
\hline
\end{tabular}

Dalam kegiatan operasionalnya, biaya distribusi menghabiskan sebesar $10,6 \%$ dan $46,6 \%$ untuk biaya persediaan dari keseluruhan biaya operasional. Hal itu dapat dilihat pada Pie chart biaya operasional PT. XYZ tahun 2019.

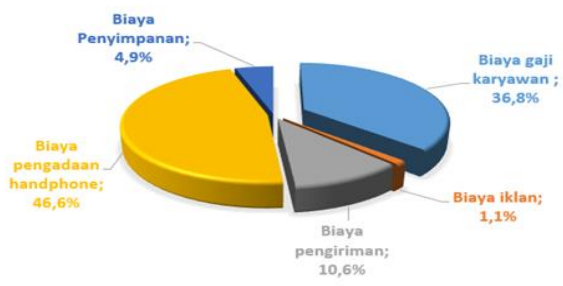

BIAYA OPERASIONAL

Gambar 1.3.Persentase Biaya Operasional PT. XYZ

Untuk itu diperlukan optimasi dalam pendistribusian dan pengadaan Handphone, mencegah kekurangan persediaan, dan membantu perusahaan menghadapi masalah dalam memelihara likuiditasnya tanpa mengurangi kualitas dalam pelayanan terhadap mitra-mitranya. Sehingga memerlukan teknik agar dalam proses pendistribusian dan pengelolaan persediaan Handphone sampai ke tangan mitranya dapat berjalan baik dengan jumlah yang tepat, waktu yang tepat serta biaya yang seminimal mungkin.

Dengan pendekatan crossdocking secara potensial dapat mengontrol biaya logistik dan distribusi karena menghilangkan beberapa proses dalam pergudangan tradisional, seperti penyimpanan dan pengambilan produk ketika 
pelanggan membutuhkan. Disamping mampu menurunkan biaya distribusi, crossdocking secara simultan meningkatkan service level pelanggan [1]. Penelitian ini bertujuan untuk memberikan usulan tekait penerapan metode crossdocking yang dapat (1) untuk menentukan rute distribusi optimal, (2) Untuk menentukan Jumlah armada distribusi optimal, (3) Untuk melakukan penjadwalan armada sehingga meminimasi makespan, (4) Untuk menentukan jumlah safety stock, (5) Untuk menentukan perbandingan total biaya persediaan kondisi saat ini dengan kondisi usulan. Definisi ideal crossdocking adalah pemindahan barang dari truk pada proses penerimaan barang langsung menuju truk pengiriman. Proses ini sebenarnya bagian dari upaya efisiensi penerimaan barang selain proses bulk storage dan proses rangking [2]. Penerapan konsep metode crossdocking ini diharapkan tidak hanya mengurangi waktu simpan, tetapi harus memastikan bahwa produk benar-benar siap untuk dikirim termasuk armada yang akan melakukan pengiriman ke gerai. Maka dari itu, perlu dilakukan penjadwalan terhadap kedatangan dan kepergian truk di distribution centre agar sesuai dengan kebutuhan metode crossdocking. Syarat-syarat dalam melakukan crossdocking antara lain [3] :

a) Barang yang diterima sama dengan barang yang akan dikirimkan.

b) Tersedia lokasi yang memadai.

c) Kuantitas jenis barang yang terbatas.

d) Jadwal kedatangan truk sama dengan jadwal keberangkatan.

\section{Metodologi}

Tahapan dalam penelian ini dapat dilakukan dengan langkah-langkah sebagai berikut :

a) Menentukan rute armada distribusi optimal, pada sistem tersebut terjadi suatu jaringan distribusi baru antara supplier, DC dan geraigerai yang akan meminimasi biaya distribusi.

b) Melakukan perhitungan jumlah armada distribusi. Pada armada tersebut akan dilakukan penggabungan produk dalam satu armada untuk memaksimalkan utilisasi dari armada tersebut.

c) Melakukan penjadwalan armada distribusi untuk memenimal makaspan. Pada tahap ini akan dilakukan penjadwalan truk untuk meminimasi makespan pada saat melakukan loading dan unloading produk dari truk supplier (truk datang) ke truk yang akan mengangkut produk ke gerai (truk berangkat)

d) Melakukan perhitungan jumlah safety stock. Pada tahap ini akan dilakukan perhitungan safety stock untuk menghindari terjadinya kekurangan stock pada perusahaan sebagai akibat dari fluktuasi permintaan

e) Melakukan perhitungan total biaya persediaan dan membandingkan kondisi saat ini dengan kondisi usulan. Pada tahap ini dapat membandingkan total biaya persediaan kondisi saat ini dengan kondisi usulan, sehingga dapat menentukan total biaya persediaan yang minimal.

\section{Hasil dan Pembahasan}

\subsection{Hasil}

\subsubsection{Penentuan Rute Armada}

Perusahaan tersebut mempunyai 20 mitra tetap dengan total jarak diukur menggunakan google maps adalah 312 menit dengan permintaan rata-rata 1.567 unit dalam satu minggu.

Tabel 3.1. Daftar Tujuan, Jarak dari Gudang \& Permintaan

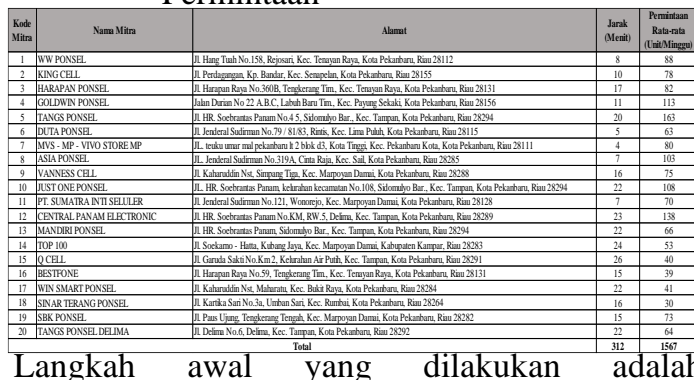
mengidentifikasi matrix jarak antara gudang ke masing-masing mitra dan jarak antar mitra.

Tabel 3.2. Matrik Jarak Gudang ke Mitra (Menit)

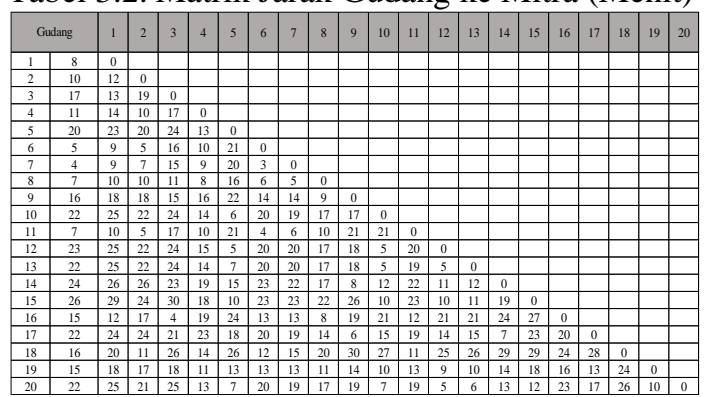

Langkah selanjutnya adalah melakukan identifikasi matrix penghematan dengan asumsi bahwa setiap mitra akan dikunjungi oleh satu armada secara eksklusif. Contoh perhitungan jarak penghematan dari gudang ke mitra 1 dan ke mitra 2 adalah sebagai berikut :

$\mathrm{S}(\mathrm{x}, \mathrm{y})=\mathrm{J}(\mathrm{G}, \mathrm{x})+\mathrm{J}(\mathrm{G}, \mathrm{y})-\mathrm{J}(\mathrm{x}, \mathrm{y})$

$\mathrm{S}(1,2)=8+10-12$

$$
=6 \text { menit }
$$

Jadi jarak penghematan dari mitra 1 ke mitra 2 sebesar 6 menit.

Tabel 3.3. Hasil Perhitungan Jarak Matrix Penghematan (Saving) 


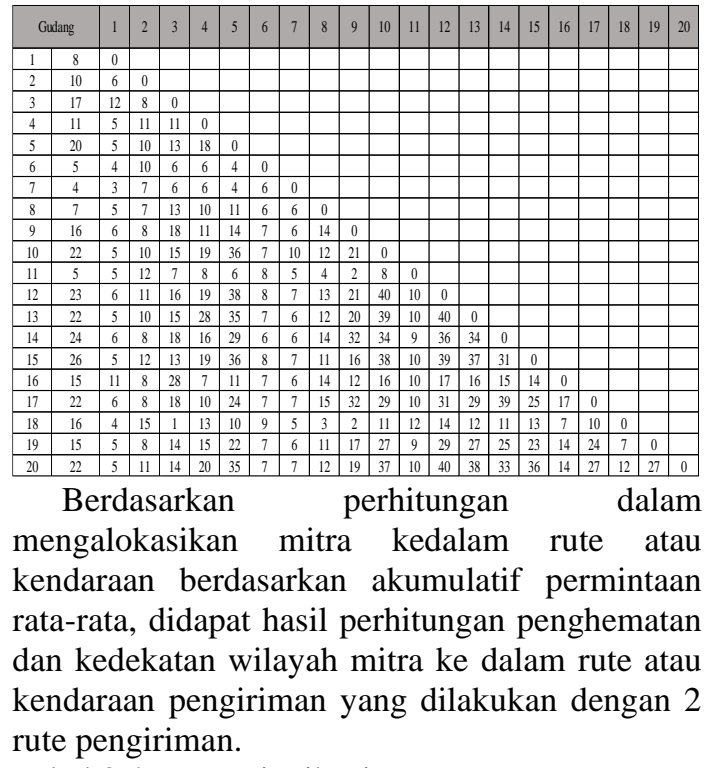

Tabel 3.4. Rute Distribusi

\begin{tabular}{|c|c|c|}
\hline Rute & Mitra & $\begin{array}{c}\text { Total Permintaan } \\
\text { (Unit) }\end{array}$ \\
\hline Rute 1 & G-12-13-20-10-5-15-18-4-2-G & 800 \\
\hline Rute 2 & G-14-17-9-16-8-11-3-1-7-6-G & 767 \\
\hline \multicolumn{2}{|c|}{ Total } & 1567 \\
\hline
\end{tabular}

Setelah alokasi rute dilakukan, langkah berikutnya adalah menentukan urutan pengiriman. Penentuan urutan pengiriman ini menggunakan metode Nearest Neighbor.

Tabel 3.5. Rekapitulasi Jarak Tempuh Rute Distribusi

\begin{tabular}{|c|c|c|}
\hline Rute & Mitra & $\begin{array}{c}\text { Jarak } \\
\text { (Menit) }\end{array}$ \\
\hline Rute 1 & G $-12-13-20-10-5-15-18-4-2-\mathrm{G}$ & 120 \\
\hline Rute 2 & G $-7-6-11-1-8-3-16-9-14-17-19-\mathrm{G}$ & 108 \\
\hline \multicolumn{2}{|c|}{ Total } & $\mathbf{2 2 8}$ \\
\hline
\end{tabular}

Tahapan dalam menentukan biaya distribusi dapat dilihat sebagai berikut :

St $=1567 / 10=156,7$ dibulatkan menjadi 157 box ( 1 box $=10$ unit)

$\mathrm{D}=800 / 10=80$ box

$\mathrm{G}=13 \mathrm{~km}$

$\mathrm{Rj}=103 \mathrm{~km}$

$\mathrm{E}=\frac{\mathrm{Rj}}{\text { Jarak tempuh/liter }} \times$ harga BBM

$=\frac{103}{13} \times 7.800=61.800$

$\mathrm{H}=1.250 .000$

$\mathrm{B}=2.250 .000$

Biaya distribusi dapat dihitung menggunakan rumus berikut :

Biaya distribusi :

$=\left[\left(\frac{S t}{D} x \frac{R j \cdot E}{G}\right)+\left(\left(\frac{S t}{D}\right) x \mathrm{H}\right)+\mathrm{B}\right]$

$=\left[\left(\frac{157}{80} \times \frac{103 \times 61.800}{13}\right)+\left(\left(\frac{157}{80}\right) \times 1.250 .000\right)+2.250 .000\right]$

$=$ 5.664.055, -

3.1.2. Penentuan Jumlah Armada
Perhitungan kebutuhan armada dilakukan dengan memperhatikan batas volume kelompok produk dengan volume armada. Apabila volume armada sudah tidak memenuhi untuk memuat produk maka tidak diperkenankan memecah volume produk dan dimasukkan pada truk selanjutnya. armada dapat dilakukan dengan rumus berikut :

a) Volume Armada 2 ton $=2000 \mathrm{~kg}=2 \mathrm{~m}^{3}$

b) Volume kardus $=0,32 \mathrm{~m} \times 0,27 \mathrm{~m} \times 0,29 \mathrm{~m}=$ $0,025 \mathrm{~m}^{3}$

c) Kapasitas volume kardus :

= banyaknya kardus yang dimuat $\mathrm{x}$ volume kardus

$=157 \times 0,025 \mathrm{~m}^{3}$

$=3,925 \mathrm{~m}^{3}$

d) Volume yang dibutuhkan

Volume kardus x kebutuhan kardus rute 1

$$
\begin{aligned}
& ==0,025 \mathrm{~m}^{3} \times\left(\frac{800}{10}\right) \\
& =2 \mathrm{~m}^{3}
\end{aligned}
$$

Volume kardus $\mathrm{x}$ kebutuhan kardus rute 2

$$
\begin{aligned}
& =0,025 \mathrm{~m}^{3} \times\left(\frac{767}{10}\right) \\
& =1,9175 \mathrm{~m}^{3} \text { dibulatkan menjadi } 2
\end{aligned}
$$

e) Kebutuhan armada

$$
\begin{aligned}
& =\frac{\text { Volume kardus }}{\text { Volume armada }} \\
& =\frac{3,9175}{2} \\
& =1,95 \text { dibulatkan menjadi } 2 \text { unit }
\end{aligned}
$$

Tabel 3.6. Kebutuhan Armada

\begin{tabular}{|c|c|c|}
\hline Rute & $\begin{array}{c}\text { Jumlah Permintaan } \\
\text { (Unit) }\end{array}$ & $\begin{array}{c}\text { Jumlah Armada } \\
\text { (Unit) }\end{array}$ \\
\hline Rute 1 & 800 & 1 \\
\hline Rute 2 & 767 & 1 \\
\hline Total & 1567 & 2 \\
\hline
\end{tabular}

\subsubsection{Penjadwalan Armada}

Penjadwalan armada dilakukan untuk armada datang serta armada berangkat menggunakan mobil grand max. Penjadwalan armada dilakukan dengan menghitung makespan dan membuat gantt chart penjadwalan armada. Perhitungan dapat dilakukan dengan rumus berikut :

Waktu selesai urutan ke 1 :

$$
\begin{gathered}
\mathrm{tj}^{k}, 1=\mathrm{tj}, 1 \\
\mathrm{tj}^{k}, 1=30 \text { menit }
\end{gathered}
$$

Waktu selesai urutan ke 2 :

$$
\mathrm{tj}^{k}, 2=\mathrm{tj}, 1+\mathrm{tj}, 2
$$

$\mathrm{tj}^{k}, 2=30+33=63$ menit

Waktu selesai urutan ke 3 :

$$
\mathrm{tj}^{k}, 3=\mathrm{tj}, 2+\mathrm{tj}, 3
$$

$\mathrm{tj}^{k}, 3=63+15=78$ menit 
Waktu selesai urutan ke 4 :

$$
\mathrm{tj}^{k}, 4=\mathrm{tj}, 3+\mathrm{tj}, 4
$$

$\mathrm{tj}^{k} 4=78+16=94$ menit

Waktu selesai urutan ke 5 :

$$
\mathrm{tj}^{k}, 5=\mathrm{tj}, 4+\mathrm{tj}, 5
$$

$\mathrm{tj}^{k} 5=94+17=111$ menit

Waktu selesai urutan ke 6 :

$$
\mathrm{tj}^{k}, 6=\mathrm{tj}, 5+\mathrm{tj}, 6
$$

$\mathrm{tj}^{k} 6=111+16=127$ menit

Waktu selesai urutan ke 7 :

$$
\mathrm{tj}^{k}, 7=\mathrm{tj}, 6+\mathrm{tj}, 7
$$

$\mathrm{tj}^{k} 6=127+20=147$ menit

Waktu mulai selesai ke 8 :

$$
\mathrm{tj}^{k}, 8=\mathrm{tj}, 7+\mathrm{tj}, 8
$$

$\mathrm{tj}^{k} 7=147+39=186$ menit

Waktu selesai urutan ke 9 :

$$
\mathrm{tj}^{k}, 9=\mathrm{tj}, 8+\mathrm{tj}, 9
$$

$\mathrm{tj}^{k} 9=186+24=210$ menit

Waktu selesai urutan ke 10 :

$$
\mathrm{tj}^{k}, 10=\mathrm{tj}, 9+\mathrm{tj}, 10
$$

$\mathrm{tj}^{k} 10=210+20=230$ menit

Waktu selesai urutan ke 11 :

\begin{tabular}{|c|c|c|c|c|c|c|c|c|c|c|c|c|c|}
\hline & \multicolumn{6}{|c|}{ WaktuProses (Menit) } & \multicolumn{6}{|c|}{ Waktu Selesai (Menit) } & \multirow{2}{*}{ Makespan } \\
\hline & & \begin{tabular}{|l|l|}
6 & 11 \\
\end{tabular} & 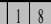 & \begin{tabular}{|l|l|}
3 & 16 \\
\end{tabular} & \begin{tabular}{|l|l|l|l|}
9 & 14 & 17 & 19 \\
\end{tabular} & & \begin{tabular}{|l|l|l}
$G$ & 7 \\
\end{tabular} & \begin{tabular}{|l|l|l|}
6 & 11 & 1 \\
\end{tabular} & \begin{tabular}{|l|l|}
8 & 3 \\
\end{tabular} & \begin{tabular}{|l|l|l|}
16 & 9 & 1 \\
\end{tabular} & \begin{tabular}{|l|l|l|}
14 & 17 & 19 \\
\end{tabular} & \begin{tabular}{l|l|}
9 & $G$ \\
\end{tabular} & \\
\hline 2 & \begin{tabular}{|l|l|}
30 & 14 \\
\end{tabular} & \begin{tabular}{|l|l|}
13 & 14 \\
\end{tabular} & 2020 & \begin{tabular}{|l|l|}
21 & 14 \\
\end{tabular} & \begin{tabular}{|l|l|l|l|}
29 & 18 & 17 & 23 \\
\end{tabular} & 2315 & \begin{tabular}{|l|l|l|l|}
30 & 4 & 5 \\
\end{tabular} & 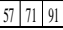 & |111| 132 & $|146| 175 \mid 1$ & & 33] 248] & 248 menit \\
\hline
\end{tabular}

$$
\begin{gathered}
\mathrm{tj}^{k}, 11=\mathrm{tj}, 10+\mathrm{tj}, 11 \\
\mathrm{tj}^{k} 11=230+10=240 \text { menit }
\end{gathered}
$$

Tabel 3.7. Rekapitulasi waktu perjalanan armada rute 1

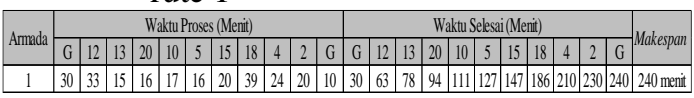

Tabel 3.8. Rekapitulasi waktu perjalanan armada rute 2

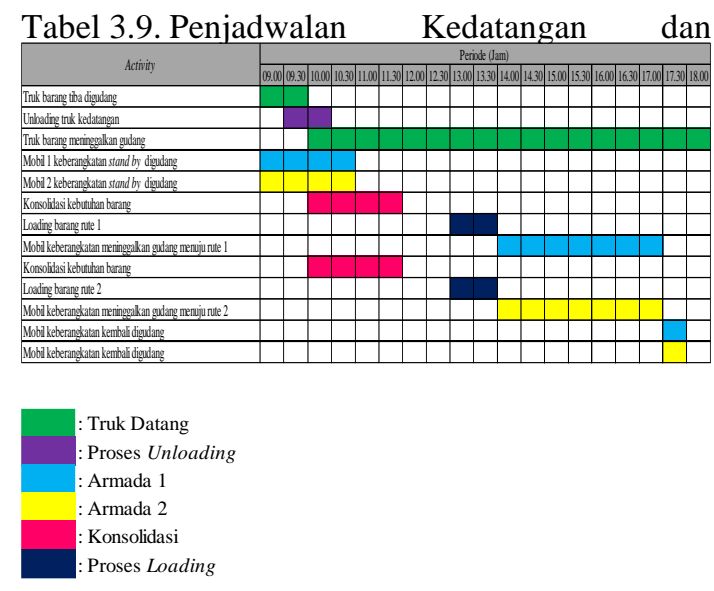

\subsubsection{Penentuan Jumlah Safety stock}

Dalam menentukan jumlah dari safety stock terlebih dahulu harus dapat mengetahui tingkat permintaan rata-rata dari masing-masing mitra dan leadtime pengiriman barang dari gudang pusat sampai ke distribution center, sebagai acuan dalam menentukan jumlah dari safety stock. Berikut data permintaan dari masing-masing mitra dengan leadtime penerimaan barang pada distribution center selama 3 hari.

Tabel 3.10. Permintaan Rata-rata Handphone VIVO

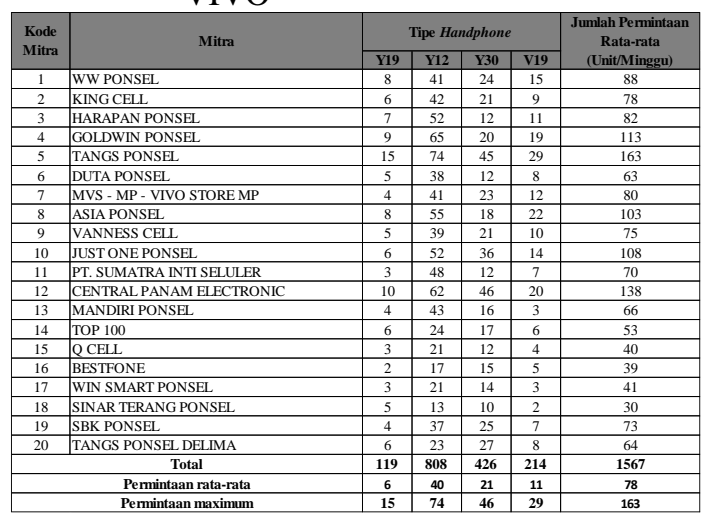

Dalam menentukan jumlah safety stock dapat dihitung menggunakan rumus berikut :

Safety stock $=($ Permintaan maximum -

permintaan rata-rata) x leadtime pengiriman.

Safety stock tipe Y19 = (15-6) x 3

$$
=27 \text { Unit }
$$

Berikut data rekapitulasi safety stock pada Handphone VIVO berdasarkan tipenya.

Tabel 3.11. Rekapitulasi Jumlah Safety stock

\begin{tabular}{|c|c|c|c|c|}
\hline No & Uraian Biaya & Qty & Amount & Jumlah \\
\hline 1 & \multicolumn{3}{|l|}{ Biaya sewa gudang } & 30.000 .000 \\
\hline 2 & Biaya listrik & 1 bulan & $\mathrm{Rp} 1.500 .000$ & 18.000 .000 \\
\hline 3 & Biaya Administrasi & 1bulan & $\begin{array}{ll}\mathrm{Rp} & 350.000 \\
\end{array}$ & 4.200 .000 \\
\hline \multirow[t]{4}{*}{4} & \multicolumn{4}{|l|}{ Biaya tenaga kerja gudang } \\
\hline & Kepala gudang & 1 orang & Rp 5.200 .000 & 62.400 .000 \\
\hline & Staff gudang @ 3.500.000 & 2 orang & Rp 7.000 .000 & 84.000 .000 \\
\hline & Helper @3.000.000 & 2 orang & Rp 6.000.000 & 72.000 .000 \\
\hline 5 & \multicolumn{4}{|l|}{ Biaya pemiliharaan } \\
\hline & $\mathrm{Y} 19$ & 324 & 1.640 & 531.360 \\
\hline & $\mathrm{Y} 12$ & 1.224 & 1.910 & 2.337 .840 \\
\hline & Y30 & 900 & 2.920 & 2.628 .000 \\
\hline & V19 & 648 & 3.920 & 2.540 .160 \\
\hline 6 & \multicolumn{3}{|l|}{ Biaya Asuransi } & 35.000 .000 \\
\hline \multicolumn{4}{|c|}{ Total } & 313.637 .360 \\
\hline
\end{tabular}
Handphone VIVO

\begin{tabular}{|c|c|}
\hline Tipe Handphone & Safety Stock (Unit) \\
\hline Y19 & 27 \\
\hline Y12 & 102 \\
\hline Y30 & 75 \\
\hline V19 & 54 \\
\hline Total & $\mathbf{2 5 8}$ \\
\hline
\end{tabular}

\subsubsection{Menghitung Total Biaya Persediaan}

a) Biaya Penyimpanan

Di bawah ini adalah rincian biaya yang dikeluarkan untuk proses penyimpanan barang persediaan selama setahun.

Tabel 3.12. Biaya Penyimpanan Handphone VIVO

Dari tabel di atas maka biaya penyimpanan per unit dapat dihitung dengan rumus berikut:

Dengan permintaan setahun $=81.484$ unit 
$\begin{aligned} \text { Besarnya biaya simpan } & =\frac{\text { Total Biaya Penyimpanan }}{\text { Total Kebutuhan Barang }} \\ \text { Besarnya biaya simpan } & =\frac{313.637 .360}{81.484} \\ \text { Besarnya biaya simpan } & =\text { Rp. } 3.849 \text { /unit }\end{aligned}$

b) Biaya Pemesanan

Biaya pemesanan merupakan biaya yang timbul pada saat pemesanan barang persediaan. Rincian biaya pemesanan dapat dilihat pada tabel Tabel 3.13. Biaya Pemesanan Handphone VIVO \begin{tabular}{|l|lr|rr|}
\hline \multicolumn{1}{|c|}{ Uraian Biaya } & \multicolumn{2}{c|}{ Amount } & \multicolumn{2}{c|}{ Jumlah } \\
\hline Biaya telpon @ Bulan & $\mathrm{Rp}$ & 400.000 & $\mathrm{Rp}$ & 4.800 .000 \\
\hline Biaya administrasi @ Bulan & $\mathrm{Rp}$ & 300.000 & $\mathrm{Rp}$ & 3.600 .000 \\
\hline Biaya transportasi @ 52 kali pemesanan & $\mathrm{Rp}$ & 7.536 .000 & $\mathrm{Rp}$ & 391.872 .000 \\
\hline \multicolumn{2}{|c|}{ Total } & & & $\mathbf{4 0 0 . 2 7 2 . 0 0 0}$ \\
\hline
\end{tabular}

Dari tabel di atas maka biaya pemesan untuk sekali pesan dapat dihitung dengan rumus berikut:

Dengan frekuensi pemesanan $=\frac{81.484}{1.567}=52 \mathrm{kali}$

Biaya pemesanan

$=\frac{400.272 .000}{52}$

$=7.697 .538$ rupiah

Biaya pemesanan (unit) $=\frac{7.697 .538}{1567}$ $=4.912$ rupiah

Dalam menentukan total biaya persediaan (Total Inventory Cost), dapat dihitung dengan tahapan sebagai berikut:

1) Total kebutuhan Handphone (D) $=81.484$

2) Pembelian ekonomis (Q) $=1.567$ unit.

3) Biaya pesan /unit $(\mathrm{S}) \quad=4.912$ rupiah.

4) Biaya penyimpanan /unit $(\mathrm{H})=3.849$ /unit

Penghitungan total biaya persediaan (TIC) adalah: $\left.=\left[\left(\frac{D}{Q} x S\right)+\left(\frac{Q}{2}\right) x \mathrm{H}\right)\right]$

$$
\begin{aligned}
& \left.=\left[\left(\frac{81.484}{1.567} \times 4.912\right)+\left(\frac{1567}{2}\right) \times 3.849\right)\right] \\
& =\text { Rp. } 2.989 .055,-
\end{aligned}
$$

Jadi total biaya persediaan yang harus ditanggung oleh perusahaan saat penerapan crossdocking adalah sebesar Rp. 2.989.055.

Tabel 3.14. Perbandingan Kondisi Saat Ini dengan Kondisi Usulan

\begin{tabular}{|c|l|c|c|}
\hline No & \multicolumn{1}{|c|}{ Keterangan } & Kondisi Saat Ini & Kondisi Usulan \\
\hline 1 & Pembelian rata-rata handphone (unit) & 1200 unit & 1567 unit \\
\hline 2 & Frekuensi pemesanan & 68 kali & 52 kali \\
\hline 3 & Safety stock & 2987 unit & 258 unit \\
\hline 4 & Total biaya persedian (TIC) dalam Rp & 4.576 .884 & 2.989 .055 \\
\hline
\end{tabular}

\subsection{Hasil}

Setelah dilakukan pengolahan data untuk mencapai tujuan yang ditetapkan, maka langkah selanjutnya dalam penelitian ini adalah melakukan pembahasan atau analisis.

3.2.1 Analisis Rute Distribusi Optimal

Penggunaan metode saving matrix mampu memperbaiki rute distribusi perusahaan dari 20 rute menjadi 2 rute dengan kapasitas 800 unit untuk rute 1, 767 unit untuk rute 2, dengan mamaksimalkan kapasitas armada sehingga bisa mengurangi biaya operasional perusahaan.
Setelah itu dikombinasikan dengan metode Nearest Neighbor mampu memperpendek jarak tempuh armada perusahaan menjadi 120 menit untuk rute 1, 108 menit untuk rute 2. Dapat dilihat pada tabel penggunaan saving matrix dan Nearest Neighbor mampu menghemat pengeluaran perusahaan sebesar $32 \%$ dalam proses distribusi.

Tabel 3.15. Perbandingan Biaya Distribusi

\begin{tabular}{|c|r|r|}
\hline Keterangan & Kondisi Saat Ini & Kondisi Usulan \\
\hline Biaya Distribusi & 432.500 .000 & 294.530 .860 \\
\hline
\end{tabular}

3.2.2 Analisis Jumlah Armada Distribusi

Dari hasil perhitungan kapasitas armada mobil grand max dengan jumlah barang yang diangkut dari 2 rute, dengan jarak tempuh 228 menit dan kapasitas 1567 unit atau 157 koli didapat jumlah armada sebanyak 2 unit. Dengan pembagian armada dapat dilihat pada tabel 3.16. Sehingga dapat menghemat pengeluaran perusahaan dalam penggunaan armada yang pada awalnya dilakukan dengan 3 unit mobil menjadi 2 unit mobil.

Tabel 3.16. Kebutuhan Armada

\begin{tabular}{|c|c|c|}
\hline Rute & $\begin{array}{c}\text { Jumlah Permintaan } \\
\text { (Unit) }\end{array}$ & $\begin{array}{c}\text { Jumlah Armada } \\
\text { (Unit) }\end{array}$ \\
\hline Rute 1 & 800 & 1 \\
\hline Rute 2 & 767 & 1 \\
\hline Total & 1567 & 2 \\
\hline
\end{tabular}

3.2.3 Analisis Penjadwalan Armada Distribusi

Untuk armada 1 melayani rute 1 mulai dari gudang sampai ke mitra-mitra dan kembali kegudang di dapat waktu makespan 240 menit, sedangkan armada 2 melayani rute 2 mulai dari gudang sampai ke mitra-mitra dan kembali kegudang di dapat waktu makespan 248 menit. Dengan adanya penjadwalan armada dapat mengontrol proses bongkar dan muat sehingga dapat meminimal makespan dan keterlambatan dalam pengiriman.

\subsubsection{Analisis Jumlah Safety stock}

Dapat dilihat pada tabel 5.21 perbandingan kondisi persediaan saat ini dan penerapan crossdocking dengan menghitung safety stock. Sehingga dapat menghemat perusahaan dalam menentukan jumlah persediaan dan tempat penyimpanan Handphone dalam gudang.

Tabel 3.17. Rekapitusi Safety stock Handphone VIVO

\begin{tabular}{|c|c|c|}
\hline Tipe Handphone & $\begin{array}{c}\text { Persediaan Saat Ini } \\
\text { (Unit) }\end{array}$ & $\begin{array}{c}\text { Kondisi Usulan } \\
\text { (Unit) }\end{array}$ \\
\hline Y19 & 325 & 27 \\
\hline Y12 & - & 102 \\
\hline Y30 & 1371 & 75 \\
\hline V19 & 1291 & 54 \\
\hline Total & $\mathbf{2 9 8 7}$ & $\mathbf{2 5 8}$ \\
\hline
\end{tabular}




\subsubsection{Analisis Perbandingan Total Biaya Persediaan}

Dari hasil perhitungan didapat total biaya persediaan (Total Inventory Cost) sebesar Rp. 2.989.055 dengan pembelian rata-rata sebanyak 1567 unit dan frekuensi pemesanan 52 kali dalam setahun. Seperti yang dapat dilihat pada tabel 5.22, dalam tabel itu didapati bahwa dengan menggunakan metode crossdocking dapat diperoleh hasil yang lebih efisien sebesar 35\% dari kondisi saat ini yang dilakukan perusahaan. Tabel 3.18. Perbandingan Biaya Persediaan

\begin{tabular}{|c|l|c|c|}
\hline No & \multicolumn{1}{|c|}{ Keterangan } & Kondisi Saat Ini & Kondisi Usulan \\
\hline 1 & Pembelian rata-rata handphone (unit) & 1200 unit & 1567 unit \\
\hline 2 & Frekuensi pemesanan & 68 kali & 52 kali \\
\hline 3 & Safety stock & 2987 unit & 258 unit \\
\hline 4 & Total biaya persedian (TIC) dalam Rp & 4.576 .884 & 2.989 .055 \\
\hline
\end{tabular}

\section{Simpulan}

Berdasarkan hasil implementasi metode dan analisa terhadap biaya distribusi dan persediaan pada PT.XYZ, maka dapat ditarik kesimpulan sebagai berikut.

1) Dari hasil penentuan rute distribusi menggunakan metode Saving Metrix dan Nearest Neigbort berdasarkan jumlah akumulatif permintaan rata-rata di dapat 2 rute, yaitu rute 1 dengan urutan G-12-13-2010-5-15-18-4-2-G dan rute 2 dengan urutan G-7-6-11-1-8-3-16-9-14-17-19-G.

2) Dari hasil penentuan rute dengan memaksimal kapasitas armada didapat jumlah armada distribusi optimal sebanyak 2 unit.

3) Dari hasil penjadwalan armada didapat makespan untuk rute 1 dengan waktu 240 menit dan armada 2 dengan waktu 248 menit.

4) Dari hasil perhitungan jumlah safety stock untuk masing-masing tipe Handphone didapat 27 unit untuk tipe Y19, 102 unit untuk tipe Y12, 75 unit untuk tipe Y30 dan 54 unit untuk tipe V19.

5) Dari hasil perhitungan total biaya persedian didapat kondisi saat ini sebesar 4.576.884 rupiah dan kondisi usulan sebesar 2.989.055 rupiah, sehingga dapat dibandingkan total biaya persedian kondisi usulan dapat menghemat biaya persedian sebesar $35 \%$.

\section{Daftar Pustaka}

[1] Apte, U.M, Viswanathan, S, 2000. Effective Cross Docking for Improfing Distribution Efficiencies. International Journal of Logistics: Research and Applications, 3(3), pp.291-302.
[2] Sutarman, 2017. Dasar-Dasar Manajemen logistik. Refika Anditama. Bandung.

[3) Kasih Putri,Talia, Antoni Hutahaean, Hotma, 2016. Usulan Konseptual Sistem Distribusi Cross Docking Untuk Meminimumkan Biaya Distribusi Pada Industri Retail, Jurnal Teknik Industri. Universitas Katolik Indonesia Atma Jaya, Jakarta.

4] Pujawan, Nyoman., Mahendrawati., 2017. Supply Chain Management-edisi 3. Andi. Surabaya.

[5] Mubin, 2013. Penerapan Konsep Crossdocking Untuk Meminimumkan Persediaan Di Pt. Coca Cola Distribusi Malang. Fakultas Teknik Universitas Muhammadiyah Malang. Malang. 